\title{
Assessing students' entrepreneurial skills needed in the Knowledge Economy
}

\author{
Ruxandra BEJINARU \\ Academy of Romanian Scientists, Bucharest, Romania \\ The University "Stefan cel Mare" of Suceava, Romania \\ ruxandrabejinaru@yahoo.com
}

\begin{abstract}
The purpose of this paper is to explore how students acquire entrepreneurial skills requested by a knowledge economy, in a country with an emergent economy. Knowledge economy is based dominantly on processing intangible resources, which needs different skills from the knowledge workers than from the industrial workers. Knowledge economy develops fast, including the countries with emergent economies like the Romania. Universities have to adapt to the requirements imposed by the knowledge economy and to change their teaching processes based on knowledge transfer into developing students' skills which will allow them to perform in a turbulent business environment. The paper focuses on the entrepreneurial skills and presents an evaluation of students' entrepreneurial skills in a Romanian university, students being enrolled in undergraduate and graduate programs of economics and business. The set of entrepreneurial skills considered in this paper have been selected based on literature, and they are expected to define the entrepreneurial behavior by the 2030 time horizon. The following skills have been considered: complex-problem solving, critical thinking, originality thinking, active learning, and judgement and decision making. For the quantitative research we developed and applied a questionnaire in order to assess the level of these skills for the students at "Stefan cel Mare" University in Suceava, Romania. We processed the obtained data set by using the specialized software package SPSS, version 25, and applied the statistical function of Exploratory Factor Analysis (EFA) for the purpose of identifying which are the main factors influencing their perceptions about the investigated categories of skills. The results of the Exploratory Factor Analysis revealed a set of 5 factors which we correlated to validate the research hypothesis. Our results show that economics and business education contributes essentially to the development of these entrepreneurial skills.
\end{abstract}

Keywords: knowledge, knowledge economy, entrepreneurial skills, intellectual capital, economics and business education, emergent economy.

Please cite this paper as follows: Bejinaru, R. (2018), “Assessing students' entrepreneurial skills needed in the knowledge economy", Management \& Marketing, Challenges for the Knowledge Society, Vol. 13, No. 3, pp. 1119-1132, DOI: 10.2478/mmcks-2018-0027.

\section{Introduction}

The knowledge economy represents that part of a country's economy in which intangible resources become more important than tangible ones in creating social value and the nation's wealth (Bejinaru, 2016; Davenport and Prusak, 2000; Hadad, 2017a, 2017b; O'Dell and Hubert, 2011; Powell and Snellman, 2004). The knowledge workers process intangible resources which are quite different than the tangible ones used extensively in the industrial economy. Since knowledge and intellectual capital is nonlinear in nature (Bratianu, 2010, 2018; Dombrowski et al., 2013; Nonaka and Takeuchi, 1995) thinking and decision making change the rules and new skills should be developed by the knowledge workers, managers and leaders (Bereiter, 2002; Bratianu and Vasilache, 2010; Drucker, 1993; Mintzberg, 
2004). According to Bratianu and Vatamanescu (2017, p. 491), “Generic skills, also known as core skills, key skills, essential skills, basic skills, soft skills, key competences, or employability skills are those capabilities which are liable to power personal and professional development based on learning". They are essential for increasing the chances of employability of the actual students and future knowledge workers in a turbulent business environment.

Entrepreneurial skills are part of these generic skills and they increase the students' capacity of thinking critically in real business context, of making successful decisions and solving complex problems, of coming with new ideas in new situations demonstrating originality skills and openness to learn from both successes and failures (Bedwell et al., 2014; Curtin, 2004; Gibbons-Wood and Lange, 2000; Sin et al., 2016). The purpose of this paper is to discuss the importance of these generic skills for countries with emergent economies which strive to implement in an accelerate way knowledge economies, and to assess how students enrolled in economics and business undergraduate and graduate programs at the University "Stefan cel Mare" of Suceava develop their entrepreneurial skills needed in the future for such a knowledge economy. The next section of the paper is focused on a literature review, and then we will present the research methodology, results and discussions. The final section will present some conclusions and limitations of this research.

\section{Literature review}

Analyzing the entrepreneurial intent in transitional economies, with a focus on Romania, Shook and Bratianu (2010, p. 244) remark the importance of research in this domain of entrepreneurship and of developing the necessary skills for the students enrolled in economics and business programs: "Evidence has been offered that Romanian students may be intensely self-motivated and focused on their own abilities when deciding to be entrepreneurs. Thus, encouraging entrepreneurship in Romania entails simultaneously increasing the students' perception of their abilities to successfully start a business, while not appearing to be overly supportive of their efforts to create a venture". The results of this research converge with those found by Cantaragiu et al. (2014, p. 405):"As the role of education in society is being transformed, universities must adapt to the challenges imposed by the competitive world by teaching their students to think and act entrepreneurially in their professional lives". A comprehensive approach to all these phenomena reveals the importance of the Bologna process, which generated a progressive convergence toward the European Higher Education Area (Bejinaru, 2017a; Dima, 2014).

In a changing world, with fast and unpredictable changes which lead to a turbulent business environment (Bolisani and Bratianu, 2017; Bratianu and Bolisani, 2015; Nonaka and Zhu, 2012; Spender, 2014), universities should not only to adapt to all these changes but to become driving forces for change and leaders in constructing new futures. Universities should develop strategies to increase their intellectual capital and to become learning organizations (Argote, 2013; Barath, 2015; Bratianu and Bejinaru, 2017; Örtenblad, 2015; Secundo et al., 2014; Senge, 1999; Zack, 1999). In the new economic landscape, universities enlarged their complex mission with the social component and become a part of the new triple helix university-government-industry, with new entrepreneurial features (Bejinaru and Prelipcean, 2017; Etzkowitz, 2013; Groves and 
Paunescu, 2008). Universities of the $21^{\text {st }}$ century should be able to become leaders of change and of innovation (Deca, 2015; Duderstadt, 2003).

Universities world-wide have the main role and the most power to develop the next generation of entrepreneurs by modelling their students throughout knowledge transfer and learning activities (Bejinaru, 2011). Formal entrepreneurial education already has a small history, as the first course on this subject was started in 1947 at the Harvard Business School (Volkmann, 2004). Ever since entrepreneurial education has been continuously gaining interest at a global scale and has been also considered that entrepreneurship will become "the major academic discipline for business education in the $21^{\text {st }}$ century" (Volkmann, 2004). In the traditional view, the focus of universities was mainly to ensure that graduates will secure the prosperity of the society in different domains of activity. Recently the missions of educational institutions have shifted towards preparing students for competing in a dynamic global environment (Dima, 2014; Nesheim and Gressgard, 2014). They reflect a growing interest of scholars for the domain of the entrepreneurship in universities regarded either from economic point of view like innovations, patents, research grants, royalties and spin off companies or in a much broad perspective like community-academic engagement (Bejinaru, 2017b; Cantaragiu et. al., 2014; Chan and Lo, 2007; Groves \& Paunescu, 2008; Paunescu, 2013).

Universities have different approaches of their entrepreneurial education programs. There are study programs that approach this discipline more theoretically by developing more the research on entrepreneurship characteristics of success, entrepreneurship management models or leadership styles. In other situations, the study programs focus more on practical learning of entrepreneurship which consists in developing practical abilities like interpersonal skills, business planning, idea creation, negotiation skills (Donate and Canales, 2012). Although there are several ways of defining a skill, "its essence is that a skill stands for the capacity of performing a certain task or activity based on an integrated knowledge content, coming from direct experience and from a mediated learning process. It engenders the consideration of both tacit and explicit knowledge" (Bratianu and Vatamanescu, 2017, p. 493). For learning some simple skills we need only practice and observation, but for developing entrepreneurial skills people need to acquire both explicit and tacit knowledge from experts and to reflect upon the risks involved in business decision making (Dombrowski et al., 2013). Regarding generic and transferable skills, Curtis (2004b, p.141) posit: "a skill is regarded as generic if observers see a skill manifested by different people in many different contexts. It is transferable if an individual who demonstrates the skill in one context is able to apply it in others". Entrepreneurial skills should be both generic and transferable.

In many countries there are ample research programs to identify and define the most important generic skills needed for the knowledge economy, such that universities to integrate in their curricula models and methods of developing them. For instance, in the United States, the report on The Secretary's Commission on Achieving Necessary Skills (SCANS) and the 21 $1^{\text {st }}$ Century Workforce Commission established by Al Gore documented these skills, which can be described briefly as follows (Curtis, 2004a, p. 23): a) basic skills literacy, numeracy, and communication; b) thinking skills - decision making, and problem solving; and c) personal qualities - responsibility, self-esteem, and integrity. In U.K., the Commission for Employment and Skills (UKCES, 2014) identified for the time horizon of 2020, the following generic skills: fluency of ideas, judgement and decision making, 
originality, active learning, system evaluation, learning strategies, complex problem solving, critical thinking, system analysis, and deductive reasoning.

Extending the time horizon up to 2030, Dawe (2004) considers the following generic skills as becoming most important: complex-problem solving, critical thinking, originality thinking, active learning, judgement and decision making. In essence, the complexproblem solving skills represents that type of soft skills which mixes together the basic abilities acquired by formal education and learning with the abilities of creative and efficient thinking applied for solving problems acquired during practical experience. This category of skills is a priority for employers who seek blue-collar workers for administrative and managerial positions and while developing the employment interviews they inquire about issues like: the capacity to analyze and frame the causes of the given problem, the creativity to generate several solutions which will lead to achieve the final goal, the capacity to decide for the final solution, the ability of implementing a complete plan and also the capacity of assessing the effectiveness of the implemented solution (Bejinaru, 2018; Curtis, 2004a; Dawe, 2004).

Critical thinking represents a superior level of generic skills which needs a continuous exercise in order to be developed. It functions like learning a sport or playing an instrument, the more you practice and the better you comply with the rules, the better you become in using those skills. It is important to acknowledge that improvement of critical thinking is not possible without conscious commitment to learn (Moore and Parker, 2007). Critical thinking skills are useful in unique situations when a new problem occurs and must be evaluated and solved. The employees who master critical thinking are easily developing a series of tasks like: identification and understanding the connections between certain ideas; acknowledging the role and relevance of arguments; building and evaluating arguments; spotting mismatches and errors of reasoning; approaching issues in a systematic and consistent manner; reflecting upon their own hypotheses, believes and values. The role of critical thinking is to judge issues in a specific way in order to achieve the best possible option in a given context (Bejinaru, 2018; Curtis, 2004a; Dawe, 2004).

Originality skills may be considered also creativity skills, though there are slight differences between them. Basically, originality skills have a larger semantic domain than the creativity ones. To have creativity skills requires two levels of action. First, it means to come up with new ideas, which actually proves you are imaginative, and second to produce the new solution and thus to bring added value as a result of the creative thinking. Originality skills are necessary for generating new solutions for new challenging issues of the VUCA (Volatility, Uncertainty, Complexity, and Ambiguity) business environment. Actually the difference reported to creativity is that originality skills enable a person to generate a different kind of ideas, unusual and smart, regarding a given problem and thus to facilitate the development of creative solutions. Though, these skills might be regarded as specific to art activities they are useful for building entirely new concepts and solutions in any domain. Acquiring originality skills depends both on innate qualities as well as on education and exercising (UKCES, 2014).

Active learning skills refer to the capacity of learning to learn and unlearn. Long life learning and wide life learning programs focus on developing those skills (UKCES, 2014). Active learning is necessary when we need to find the optimal solution of a problem, to develop a new product, during a live discussion or while working in project teams (De Boer and Winnips, 2015). In this sense, active learning skills require superior levels of thinking, of motivation and also of acting which will ensure successful results on the long run due to easier adaptation to various conditions and requirements. As Drucker (1993, p. 24) remarks, "The productivity of people requires, finally, continuous learning, as the Japanese have taught us. It requires that 
people are constantly challenged to think through what they can do to improve what they are already doing. It requires adoption in the West of the specific Japanese Zen concept of learning: that one learns in order to do better what one already knows how to do well".

Judgement and decision making skills are essential in any decision making process. Although everybody is making decisions, we are looking for developing the capacity of making good and very good decisions, especially in conditions of uncertainty and limited information. A good level of judgement and decision making skills will provide the individual selecting the best option regarding a certain issue. Judgement and decision making skills are now necessary at any organizational level because the rhythm of all activities and procedures is speeding up and good decisions are required at every moment, and in any business context (Spender, 2014).

\section{Research methodology}

For the present research we combined qualitative and quantitative methods in order to integrate their advantages (

For the theoretical argument of the researched topic we used the method of literature review. For the validation of the presented theories we used quantitative methods by applying a questionnaire. The investigation instrument contained 30 items with 5 Likert scale levels.

We elaborated the items of the questionnaire in order to identify the opinions of respondents regarding their level of acquiring 5 types of competencies. In other words, the main objective was to investigate the perspectives of students from Business Bachelor and Master programs from „Stefan cel Mare” University of Suceava in Romania (a public higher education institution) with respect to their level of acquiring five type of skills while attending their study programs. For this purpose we formulated five hypotheses, as follows:

H1: Students consider they have been acquiring 'complex problem solving' skills.

H2: Students consider they have been acquiring 'critical thinking' skills.

H3: Students consider they have been acquiring 'originality' skills.

H4: Students consider they have been acquiring 'active learning' skills.

H5: Students consider they have been acquiring 'judgement and decision making' skills.

The results obtained could be useful to determine a strategy of prioritizing the teaching agenda in order to deliver the necessary skills to be developed for the category of students enrolled in the investigated programs.

By using the Google platform - Event Feedback, we applied the questionnaire to students enrolled in the Business Bachelor and Master degree programs from the Faculty of Economics and Public Administration of the University "Stefan cel Mare" of Suceava. We collected 516 valid questionnaires that we processed using SPSS, version 25. First we checked the statistical validation tests and afterwards we performed the Varimax Factorial Analysis in order to obtain a hierarchy for the resulted main factors (Arkkelin, 2014; O'Connor, 2000). The Varimax type of rotation, when performing a Factor Analysis is the most popular because it groups together the items with the most similar evolution and thus simplifies their observation and interpretation. This type of statistical protocol facilitates the researcher's work as it provides a more simplified structure of the investigated data (De Winter et al., 2009; Sass, 2009; Panter et al., 1997).

The main purpose of this research is to identify and interpret the factors formed by grouping the items in the questionnaire based on the opinions expressed by respondents, 
namely bachelor and master students. The interpretation of the results will lead us to a better awareness of their level of knowledge, of their preferences in terms of acquiring certain generic skills as well as of the needs related to the educational program and the teaching methods. At micro level, the effect will be on improving education curricula, and at macro level, the effect will be to increase students' potential as parts of the human capital in the knowledge-based economy (Bejinaru, 2018).

\section{Statistical tests and Exploratory Factor Analysis (EFA)}

Providing statistical processing steps is required in such research, and in this case we have applied the Bartlett and Kaiser-Meyer-Olkin (KMO) tests (Table 1). Values of these tests indicate validation for applying this type of statistical analysis to the collected data. The KMO test has a value of 764, indicating sufficient suitability for the application of statistical analysis methods. If the KMO test value was less than 0.7, then it would question the adequacy of the method. For the studies conducted, the two tests, Bartlett and KMO, indicate excellent accuracy for the use of analytical factors.

Table 1. KMO and Bartlett's Test

\begin{tabular}{|l|l|r|}
\hline \multicolumn{2}{|l|}{ Kaiser-Meyer-Olkin Measure of Sampling Adequacy. } &, 764 \\
\hline \multirow{3}{*}{ Bartlett's Test of Sphericity } & Approx. Chi-Square & 4331,347 \\
\cline { 2 - 3 } & df & 435 \\
\cline { 2 - 3 } & Sig. &, 000 \\
\hline
\end{tabular}

The next step for accomplishing the analysis of factors was to identify the most appropriate factor rotation option. In this sense, after rationalizing according to the known criteria, we determined the analysis of the main factors with Varimax rotation. As mentioned earlier, this type of rotation is advantageous with respect to the current database as it has the advantage of maximizing the variation of factor components and results in lower loadings of variables for each factor. However, this type of rotation may sometimes be inappropriate for exploratory factor analysis if variables tend to have a high degree of correlation (Gorsuch, 1997). In this case, applying this method eliminates data redundancy (Arkkelin, 2014). Following the application of the statistical functions presented above, the program returned to the first round of rotation nine factors that are representative of $70,225 \%$ of the replies recorded in the original database (Table 2).

Table 2. Total Variance Explained

\begin{tabular}{|l|r|r|r|}
\hline \multirow{2}{*}{ Component } & \multicolumn{3}{|c|}{ Initial Eigenvalues } \\
\cline { 2 - 4 } & Total & \% of Variance & Cumulative \% \\
\hline 1 & 8,341 & 27,802 & 27,802 \\
\hline 2 & 2,330 & 7,766 & 35,568 \\
\hline 3 & 2,024 & 6,746 & 42,313 \\
\hline 4 & 1,860 & 6,202 & 48,515 \\
\hline 5 & 1,774 & 5,913 & 54,428 \\
\hline 6 & 1,311 & 4,369 & 58,797 \\
\hline 7 & 1,184 & 3,948 & 62,745 \\
\hline 8 & 1,133 & 3,777 & 66,523 \\
\hline 9 & 1,111 & 3,702 & 70,225 \\
\hline 10 &, 878 & 2,927 & 73,152 \\
\hline 11 &, 838 & 2,794 & 75,946 \\
\hline
\end{tabular}




\begin{tabular}{|l|r|r|r|}
\hline 12 &, 752 & 2,506 & 78,451 \\
\hline 13 &, 710 & 2,368 & 80,819 \\
\hline 14 &, 684 & 2,280 & 83,099 \\
\hline 15 &, 630 & 2,098 & 85,198 \\
\hline 16 &, 582 & 1,942 & 87,139 \\
\hline 17 &, 540 & 1,800 & 88,939 \\
\hline 18 &, 432 & 1,439 & 90,378 \\
\hline 19 &, 359 & 1,198 & 91,576 \\
\hline 20 &, 349 & 1,162 & 92,738 \\
\hline 21 &, 344 & 1,147 & 93,885 \\
\hline 22 &, 322 & 1,073 & 94,958 \\
\hline 23 &, 261 &, 869 & 95,827 \\
\hline 24 &, 250 &, 834 & 96,661 \\
\hline 25 &, 235 &, 784 & 97,445 \\
\hline 26 &, 199 &, 664 & 98,109 \\
\hline 27 &, 190 &, 633 & 98,742 \\
\hline 28 &, 149 &, 495 & 99,237 \\
\hline 29 &, 120 &, 400 & 99,637 \\
\hline 30 &, 109 &, 363 & 100,000 \\
\hline
\end{tabular}

The basic idea is, that for this type of analysis, a factor is the equivalent of a latent variable, which is unknown previously, and which we will finally be able to analyze, understand and name according to its content. The factors loading model provides information in this regard. For example, if the load values are greater than 0.6 then they are considered important variables and the lowest of 0.4 are considered to be low and less relevant. In order to obtain a conclusive result, it is necessary to refer to the highest loading values because they are the ones that determine the factors and which are most relevant in factors formation.

According to this criterion, we were entitled to process a second Varimax rotation by specifying a value for factor loading higher than 0.5 and a predetermined number of factors in order to achieve convergence with the previously expressed research assumptions. Thus, in the following, we will analyze in Table 3 the component of the 5 factors according to the highest values and then we will name them according to the information observed in their structure.

Table 3. Rotated Component Matrix ${ }^{a}$

\begin{tabular}{|l|l|l|c|c|c|}
\hline \multirow{2}{*}{ Items } & \multicolumn{5}{|c|}{ Factor } \\
\hline & 1 & 2 & 3 & 4 & 5 \\
\hline Q 05. &, 687 & & & & \\
\hline Q 27. &, 648 & & & & \\
\hline Q 25. &, 640 & & & & \\
\hline Q 18. &, 624 & & & & \\
\hline Q 15. &, 620 & & & & \\
\hline Q 11. &, 517 & & & & \\
\hline Q 08. &, 423 & & & & \\
\hline Q 09. & &, 747 & & & \\
\hline Q 07. & &, 730 & & & \\
\hline Q 19. & &, 595 & & & \\
\hline Q 24. & &, 537 & & & \\
\hline Q 28. & &, 529 & & & \\
\hline Q 22. & &, 472 & & & \\
\hline Q 06. & & &, 871 & & \\
\hline Q 16. & & &, 742 & & \\
\hline Q 04. & & &, 545 & & \\
\hline
\end{tabular}




\begin{tabular}{|l|l|l|r|r|r|}
\hline Q 02. & & &, 504 & & \\
\hline Q 14. & & &, 462 & & \\
\hline Q 29. & & &, 458 & & \\
\hline Q 03. & & &, 417 & & \\
\hline Q 23. & & &, 649 & \\
\hline Q 01. & & & &, 648 & \\
\hline Q 17. & & &, 608 & \\
\hline Q 12. & & & &, 589 & \\
\hline Q 21. & & &, 501 & \\
\hline Q 30. & & & &, 429 & \\
\hline Q 13. & & & &, 757 \\
\hline Q 20. & & & & &, 539 \\
\hline Q 26. & & & & &, 518 \\
\hline Q 10. & & & &,- 497 \\
\hline \\
Extraction Method: Principal Component Analysis. \\
Rotation Method: Varimax with Kaiser Normalization. \\
\hline \\
a. Rotation converged in 12 iterations. \\
\hline
\end{tabular}

As a result of the factorial analysis, we will continue to present tables with descriptive statistics and internal consistency tests of the 5 factors. We are once again arguing that the decision on the components of the factors was based on the criterion of the highest load values and we considered the decreasing ordering. For example, for factor 1 , the higher values are recorded by the first 7 variables and these are the most representative for respondents' opinions. The same rule we applied to identifying the other factors. In this context, factor 1 consists of the following items: Q5, Q27, Q25, Q18, Q15, Q11, Q8; factor 2 comprises the following items: Q9, Q7, Q19, Q24, Q28, Q22; factor 3 comprises items: Q6, Q16, Q4, Q2, Q14, Q29, Q3; factor 4 contains the items: Q23, Q1, Q17, Q12, Q21, Q30; and factor 5 consists of items: Q13, Q20, Q26. Below in table 4 we will present the tests to validate the compliance of factors and also the Mean values of factors.

Table 4. Reliability and Descriptive Statistics of Factors

\begin{tabular}{|l|r|r|r|r|}
\hline $\begin{array}{l}\text { Factors } \\
\text { ranking }\end{array}$ & \multicolumn{2}{|l|}{$\begin{array}{l}\text { Cronbach's } \\
\text { Alpha }\end{array}$} & $\begin{array}{l}\text { Cronbach's Alpha Based } \\
\text { on Standardized Items }\end{array}$ & \multicolumn{2}{l|}{ N of Items } & \multicolumn{1}{l|}{ Mean } \\
\hline Factor 1 &, 776 &, 785 & 7 & 4,25 \\
\hline Factor 2 &, 779 &, 782 & 6 & 4,30 \\
\hline Factor 3 &, 787 &, 780 & 7 & 3,91 \\
\hline Factor 4 &, 742 &, 751 & 6 & 3,86 \\
\hline Factor 5 &, 649 &, 655 & 3 & 3,64 \\
\hline
\end{tabular}

For each of the five factors we have applied the internal consistency tests to assess the reliability of all the variables contained therein. Generally, values higher than 0.7 show a very good internal consistency. As it can be observed from Tabel 5, the values of the Means decrease in accordance with the ranking of the factors.

For factor 1 , the Cronbach alpha test returned the value 0.776 which confirms the fact that the 7 variables contained the greatest influence regarding the perspective of the respondents regarding 'judgement and decision making' skills. The highest value of the Mean $=4.25$, for factor 1 , confirms the fact that respondents acknowledge as a majority the 
major importance of these skills and consider they are in the process of acquiring them during the bachelor and master education cycles. Thus, it can be associated also to the perspective that these students are studying for becoming business man, managers or highly specialized professionals so they deeply understand the importance of such skills for efficient judgement and decision making.

The $2^{\text {nd }}$ factor revealed by the Rotation Matrix (Table 4) contains 6 items which refer as a main perspective to the category of 'complex problem solving' skills. This factor has the second high value of the Mean, which stands for the fact that this category of skills ranks in the second position for the students interests of learning. This fact indicates a certain thinking pattern of this profile of students attending business education programs which strongly bends towards pragmatism and complex problem solving within the real world.

Factor number 3 consists of items which reflect the category of 'critical thinking' skills. Ranking third, these skills are also very important in the perspective of respondents, fact which makes them really interested in acquiring this type of skills. Respondents were inquired about these skills with questions like: "I prefer professors who set challenging tasks as homework", or "I prefer to search and analyze myself the information I need for a certain task". The composition of this factor, of 7 items, showed that the skills of 'critical thinking' are perceived in different ways by graduates and undergraduates.

Regarding factor 4 we have noticed that the 6 items included reflect issues about the 'originality' skills. The Cronbach alpha test value is .742 indicating that the components included are representative and confirm a very good internal consistency. The high values of these variables that have been grouped together to form factor 4 mostly reflect the students' perceptions regarding the accumulation of 'originality' skills. Although the Mean's value for this factor is the second lowest 3.86, we consider that students unconsciously manifest a slight reluctance to whether they are able to acquire the skills of creativity and originality. However, identifying this group of items really reflects the interest in developing a way of thinking and action defined by 'originality' through which graduates will later generate the competitive edge within the organizations they will work.

Factor 5 registered the lowest value for the Mean $=3.64$ which reflects that respondents had the lowest options regarding issues of 'active learning' skills. The most plausible explanation is the theory that respondents are not familiar with the concept of 'active learning' and thus do not fully understand the aspects and implications of this concept. The term 'learning' has definitely been sensitizing given that students have offered values to items such as "Learning is a process to be continued after graduation", "It is fundamental to learn how to learn", or "Good learning must have a good motivation". One possible explanation for the last position in the ranking of this factor could be that students have superficially appreciated these items by considering their basic learning abilities without being an asset.

In conclusion to the EFA (Exploratory Factor Analysis) we relate the obtained results to the formulated hypothesis at the beginning of the research. Thus, we conclude that validation of the research states hypothesis were validated in accordance to the Factors' Rotated Matrix. In this sense, we consider that the factors' formation and ranking resulted after statistical processing represents the validation of the previously formulated hypothesis. We review each hypotheses related to the factor that ensured its validation, as following: 
- H1: Students consider they have been acquiring 'complex problem solving' skills, has been validated throughout the formation of factor 2;

- H2: Students consider they have been acquiring 'critical thinking' skills, has been validated throughout the formation of factor 3 ;

- H3: Students consider they have been acquiring 'originality' skills, has been validated throughout the formation of factor 4 ;

- H4: Students consider they have been acquiring 'active learning' skills, has been validated throughout the formation of factor 5 ;

- H5: Students consider they have been acquiring 'judgement and decision making' skills, has been validated throughout the formation of factor 1 .

We consider, that throughout this research we have achieved a general perspective from students' behalf about their level of acquiring five categories of crucial skills for their future in the labor market. It is a fact that ranking of the factors revealed the students perceptions towards the investigated issues and thus the top values show their 'preferences' while evaluating the level of certain categories of skills.

\section{Conclusions and limitations}

In the adaptation process, universities focus on their traditional mission of teaching, learning and research. Today, society asks much more from universities in terms of their contribution. They have to develop the third mission which refers to delivering services toward society and to be a part of the triple helix university-government-industry.

Against this backdrop, universities should contribute more to the developing generic skills of students and to stimulate their intention toward entrepreneurship, especially in the countries with emergent economies like Romania. This challenge for our universities triggered the present research for assessing the entrepreneurial skills of the students enrolled in economics and business programs at the University "Stefan cel Mare" of Suceava. We performed a quantitative research based on a questionnaire which have been answered by 516 students from our undergraduate and graduate programs.

Briefly to review the main ideas of our research we would reiterate that the results of the Exploratory Factor Analysis have confirmed the assumptions we made regarding the acquisition of skills which registered heterogeneous levels according to students' responses. The difference resides in the interpretation of the factors' composition in order to determine if students recognize the categories of skills and how they perceive their level of acquisition. Thus we can observe that the perspective preferred by students is reflected by the factors' ranking: a) in the first instance we can deduce that they have the best perception about their acquisition of 'judgement and decision making' skills; b) secondly we observe that a similar perception corresponds to 'complex problem solving' skills, maybe as being coupled with the previous type of skills; c) the third place, according to their preferences reveals the category of 'critical thinking' skills, related to which we have noticed a careful approach as it registered lower values for the statistical indicators; d) factor number four, shows that students have a cautious attitude towards the activities that imply a creative way of solving problems and require 'originality' skills; and e) about factor number five we can argue that, due to the fact that it ranked last, it implies that students have the lowest opinion about their level of 'active learning' skills. 
The research topic of universities preparing to provide students with the best skills is strongly related to strategic thinking and developing knowledge strategies at the levels of rectorate of any university. That will improve the contribution of our universities to economic and social value creation and to increasing their role in accelerating the development of our economy. That is in concordance with the forthcoming European Union's and governmental strategies of strengthening our educational system and its role in society. Finally, education and training suppliers should have the vision of their future as a dual model with the business sector in order to stay in touch with the market, to better meet the employers' needs.

The limits of this research are given by the investigated sample, which was located in a specific Romanian state university, presenting as such a contextual perspective. The survey about the top categories of skills necessary for 2030 could be extended at national level but with a more thorough revision of the investigating instrument construction (i.e. revision of the questionnaire). Also, the investigation should be extended to the business environment to get the vision of different firms about the necessary generic skills needed in the knowledge economy in the near future.

Acknowledgements: The present paper has been financially supported by the Academy of Romanian Scientists, Program No. 15/2018 "Strategies for Implementing Knowledge Economy in Romania".

\section{References}

Arkkelin, D. (2014), Using SPSS to understand research and data analysis, Psychology Curricular Materials. Book 1.

Argote, L. (2013), Organizational learning: creating, retaining and transferring knowledge, 2nd edition, Springer, New York.

Barath, T. (2015), "Learning organization as a tool for better and more effective schools", Procedia Manufacturing, No.3, pp. 1494 - 1502, Elsevier.

Bedwell, W.L., Fiore, S.M. and Salas, E. (2014), “Developing the future workforce: an approach for integrating interpersonal skills into the MBA classroom", Academy of Management Learning \& Education, Vol. 13, No. 2, pp. 171-186.

Bejinaru, R. (2018), "Factorial analysis perspectives upon students' skills in the knowledge economy", Management Dynamics in the Knowledge Economy, Vol. 6, No. 2, pp. 265284.

Bejinaru, R. (2017a), "Universities in the knowledge economy”, Management Dynamics in the Knowledge Economy, Vol. 5, No.2, pp. 251-271.

Bejinaru, R. (2017b),"Knowledge strategies aiming to improve the intellectual capital of universities", Management \& Marketing. Challenges for the Knowledge Society, Vol. 12, No. 3, pp. 500-523.

Bejinaru, R. (2016),"Knowledge dynamics impact on intellectual capital in organizations", Management Dynamics in the Knowledge Economy, Vol. 4, No. 4, pp. 515-534.

Bejinaru, R. (2011),"Knowledge dynamics and the concept of BA", The USV Annals of Economics and Public Administration, Vol. 10, No. 3, pp. 217-223.

Bejinaru, R. and Prelipcean, G. (2017), "Successful strategies to be learnt from world-class universities", Management and Marketing, Vol. 11, No.1, pp. 350-358. 
Bereiter, C. (2002), Education and mind in the knowledge edge, Routledge, London.

Bolisani, E. and Bratianu, C. (2017),"Knowledge strategy planning: an integrated approach to manage uncertainty, turbulence, and dynamics", Journal of Knowledge Management, Vol. 21, No. 2, pp. 233-253.

Bratianu, C. (2010), "A critical analysis of Nonaka's model of knowledge dynamics", in Rodrigues, S. (ed.), Proceedings of the $2^{\text {nd }}$ European Conference on Intellectual Capital, ISCTE Lisbon University Institute, Lisbon, Portugal, 29-30 March 2010, pp. 115-120, Academic Conferences and Publishing International, Reading.

Bratianu, C. (2018), "Intellectual capital research and practice: 7 myths and one golden rule", Management \& Marketing. Challenges for the Knowledge Society, Vol. 13, No. 2, pp.859-879.

Bratianu, C. and Bejinaru, R. (2017),"Knowledge strategies for increasing IC of universities", in Lopez, I.T. and Serrasqueiro, R. (eds.), Proceedings of the $9^{\text {th }}$ European Conference on Intellectual Capital, Institute Universitario de Lisboa (ISCTE), Portugal, 6-7 April 2017, pp. 34-42, Academic Conferences and Publishing International, Reading.

Bratianu, C. and Bolisani, E. (2015), "Knowledge strategy: an integral approach for managing uncertainty, in Massaro, M. and Garlatti, A. (eds.), Proceedings of the $16^{\text {th }}$ European Conference on Knowledge Management, University of Udine, Italy, 3-4 September 2015, pp. 169-177, Academic Conferences and Publishing International, Reading.

Bratianu, C. and Vasilache, S. (2010), "A factorial analysis of the managerial linear thinking model", International Journal of Innovation and Learning, Vol. 8, No. 4, pp. 393-407.

Bratianu, C. and Vatamanescu, E.M. (2017), "Students' perception on developing conceptual generic skills for business: a knowledge-based approach, VINE Journal of Information and Knowledge Management Systems, Vol. 47, No. 4, pp. 490-505.

Cantaragiu, R., Paunescu, C. and Hadad, S. (2014), "The social impact of university entrepreneurship in Romania: is the institutional discourse replicated or adopted?", Management \& Marketing. Challenges for the Knowledge Society, Vol. 9, No. 4, pp. 403-422.

Chan, D. and Lo, W. (2007), "Running universities as enterprises: university governance changes in Hong Kong", Asia Pacific Journal of Education, Vol. 27, No. 3, pp. 305-322.

Curtin, P. (2004), "Employability skills for the future", in Gibb, J. (ed.), Generic skills in vocational education and training. Research readings, National Center for Vocational Educational Research, Adelaide, pp. 38-68.

Curtis, D.D. (2004a),"The assessment of generic skills", in Gibb, J. (ed.), Generic skills in vocational education and training. Research readings, National Center for Vocational Education Research, Adelaide, pp. 136-156.

Curtis, D.D. (2004b),"International perspectives engineering skills", in Gib, J. (ed.), Generic skills in cocational education and training. Research readings, National Center for Vocational Education Research, Adelaide, pp. 19-37.

Davenport, T.H. and Prusak, L. (2000), Working knowledge: how organizations manage what they know, Harvard Business School Press, Boston.

Dawe, S. (2004), Focusing on generic skills in training packages, National Center for Vocational Education Research, Leabrook. 
De Boer, V., \& Winnips, K. (2015), "Flipped classroom at the University of Groningen", University of Groningen. Retrieved from http://www.rug.nl/e-learning/project en/flipped-classroom.

Deca, L. (2015), “Challenges for Romanian higher education”, International Higher Education, Vol. 82, pp.16-18.

De Winter, J. C. F., Dodou, D. and Wieringa, P.A. (2009), "Exploratory factor analysis with small sample sizes”, Multivariate Behavioral Research, Vol. 44, No. 2, pp. 147-181.

Dima, A.M. (2014), Trends in European higher education convergence, IGI Global, Hershey.

Dombrowski, E., Rotenberg, L. and Bick, M. (2013), Theory of knowledge, Oxford University Press, Oxford.

Donate, M.J. and Canales J.I. (2012), “A new approach to the concept of knowledge strategy", Journal of Knowledge Management, Vol.16 No. 1, pp.22-44.

Drucker, P.F. (1993), Managing in turbulent times, Harper Business, New York.

Duderstadt, J.J. (2003), A university for the 21st century, The University of Michigan Press, Ann Arbor.

Etzkowitz, H. (2013),"Anatomy of the entrepreneurial university", Social Science Information, Vol. 52, No. 4, pp. 515-538.

Gibbons-Wood, D. and Lange, T. (2000)," Developing core skills - lessons learned from Germany and Sweden", Education + Training, Vol. 42, No. 1, pp. 24-32.

Gorsuch, R. L. (1997), "Exploratory factor analysis: its role in item analysis", Journal of Personality Assessment, Vol. 68, No. 3, pp. 532-560.

Groves, K. and Paunescu, C. (2008), Examining the antecedents and outcomes of Romanian entrepreneurial orientation, Management \& Marketing, Vol. 3, No.11, pp. 3-18.

Hadad, S. (2017a), "Knowledge economy: characteristics and dimensions”, Management Dynamics in the Knowledge Economy, Vol.5, No. 2, pp. 203-225.

Hadad, S. (2017b),"Strategies for developing knowledge economy in Romania", Management \& Marketing. Challenges for the Knowledge Society, Vol. 12, No. 3, pp. 416-430.

Mintzberg, H. (2004), Managers not MBAs: a hard look at the soft practice of managing and management development, Financial Times/Prentice Hall, London.

Moore, B.N. and Parker, R. (2007), Critical thinking, 8th edition, McGraw Hill, New York.

Nesheim, T. and Gressgard, L.G. (2014), "Knowledge sharing in a complex organization: antecedents and safety effects", Safety Science, Vol. 62, pp.28-36.

Nonaka, I. and Takeuchi, H. (1995), The knowledge-creating company. How Japanese companies create the dynamics of innovation, Oxford University Press, Oxford.

Nonaka, I. and Zhu, Z. (2012), Pragmatic strategy. Eastern wisdom, global success, Cambridge University Press, Cambridge, UK.

O'Connor, B. P. (2000), "SPSS and SAS programs for determining the number of components using parallel analysis and velicer's MAP test", Behavior Research Methods, Instruments \& Computers, Vol. 32, No. 3, pp. 396-402.

O'Dell, C. and Hubert, C. (2011), The new edge in knowledge: how knowledge management is changing the way we do business, John Wiley \& Sons, New York.

Örtenblad, A. (2015), "Towards increased relevance: context-adapted models of the learning organization", The Learning Organization, Vol. 22, No. 3, pp.163 - 181.

Paunescu, C.M. (2013). Challenges of entering the business market: the pre-entry knowledge and experience. Management \& Marketing, Vol. 8, No. 1, pp. 63-78. 
Panter, A. T., Swygert, K. A., Dahlstrom, W. G. and Tanaka, J. S. (1997), "Factor analytic approaches to personality item-level data", Journal of Personality Assessment, Vol. 68, pp. 561-589.

Powell, W.W. and Snellman, K. (2004), "The knowledge economy", Annual Review of Sociology, Vol. 30,pp. 199-220.

Sass, D. (2009), "Factor loading estimation error and stability using exploratory factor analysis", Educational and Psychological Measurement, Vol. 70, No. 4, pp. 557-577.

SCANS (Secretary's Commission on Achieving Necessary Skills) (1991), What work requires of school: a SCANS report for America 2000, U.S. Department of Labor, Washington, D.C.

Secundo, G., Elena Perez, S., Martinaidis, Z. and Leitner, K.H. (2014), "Intellectual capital management in European universities in times of changes: an IC maturity model", IFKAD, University of Basilicata, Italy, 11-13 June 2014, Matera, pp. 1095-1113.

Senge, P. (1999), The fifth discipline: the art \& practice of the learning organization, Random House.

Shook, C. and Bratianu, C. (2010),"Entrepreneurial intent in a transitional economy: an application of the theory of planned behavior to Romanian students", International Entrepreneurship and Management Journal, Vol.6, No.3, pp. 231-247.

Sin, C., Taveres, O. and Amaral, A. (2016), "Who is responsible for employability? Student perceptions and practices", Tertiary Education and Management, Vol. 22, No. 1, pp. $1-18$.

Spender, J.C. (2014), Business strategy. Managing uncertainty, opportunity \& enterprise, Oxford University Press, Oxford.

UKCES (2014) The future of work jobs and skills in 2030, by UK Commission for Employment and Skills, accessed on 22nd April 2018 at https://assets.publishing.service.gov.uk/government/uploads/system/uploads/att achmentdata/file/303334/er84-the-future-of-work-evidence-report.pdf

Volkmann, C. (2004), Entrepreneurship studies - an ascending academic discipline in the twenty-first Century, Higher Education in Europe, Vol. 29, No. 2, pp. 177-185.

Zack, M.H. (1999), "Developing a knowledge strategy", California Management Review, Vol.41, No.3, pp.125-145. 